SWITCHING BEHAVIOR

J. SOLE

J. DOMINGO

J. GARCIA

RR $\quad 06 / 89$ 


\title{
TRAFFIC BURSTINESS INFLUENCE ON ATM SWITCHING
}

\section{BEHAVIOR}

Josep Solé, Jordi Domingo, Jorge García

Universitat Politècnica de Catalunya

Departament d'Arquitectura de Computadors

Phone number: + 4334016982
Facultat d'Informàtica de Barcelona

Pau Gargallo, 508028 BARCELONA (Spain)

\begin{abstract}
Traffic studies is an important subject to evaluate the performance of the switching elements in an ATM environment. The main reason is that ATM cell streams have a varible bitrate where the maximum peak bitrate can be several times the mean bitrate. Furthermore, the length of the bursts is a key parameter to be taken into account.
\end{abstract}

In this paper we present a study of the switching blocs behavior with bursty cell streams. We characterize the bursty cell stream by the mean duration of the bursts (high activity periods), its mean traffic intensity, the mean interval of time between bursts, and the mean traffic i, itensity of these low activity periods. A bursty cell stream source is developed for this study so that we can evaluate the switching bloc varying the burst length and its traffic intensity. This is an alternative measurement method to the one based on the mean traffic intensity at the input port of the switching bloc.

From the results obtained, some interesting design considerations for the switching bloc architectures follow. 


\begin{abstract}
e
Un dels aspectes més destacables de l'entorn ATM (Asynchronous Transfer Mode) és que el flux de les seqüències de cel.les és força fructuant, la distància entre el seu valor màxim i la mitjana pot arribar a ser considerable. Per això l'estudi del tràfic és un element de gran importància per a l'avaluació de les estructures dels commutadors que s'haigin d'usar en aquest entorn. En aquest sentit, un dels paràmetres clau a considerar és la dimensió de les ràfegues (intervals d'alta activitat) de les seqüències de cel.les.
\end{abstract}

En aquest article es presenta una anàlisi del comportament dels commutadors en presència de tràfic a ràfegues. La seqüència de cel.les s'ha caracteritzat per al durada mitjana de les ràfegues, l'interval mitjà entre ràfegues i les intensitats mitjanes de tràfic respectives en cada un d'aquests períodes; desenvolupant-se un model de font específic per a aquest estudi que permetés l'avaluació del commutador variant la llargària de les ràfegues i la seva intensitat de tràfic. Aquest mètode es proposa com una alternativa a l'avalució basada en la variació de la intensitat mitjana de tràfic als ports d'entrada del commutador.

Dels resultat obtinguts per simulació sobres una estructura de commutador en matriu de busos se'n posen desprendre consideracions de gran interés pel disseny d'arquitectures de commutador 


\section{Introduction}

Switching blocs are important elements of the broadband communication network. The switching function is located at several elements of the network, specified in the reference configuration of the IBCN, as NT2 (Network Terminal), LEX (Local Exchange) and TEX (Trunk Exchange), and being the main difference the size of the switching blocs. Those switching blocs can determine the behavior, or the quality of service, of the overall communication network.

Bandwidth allocation flexibility is a basic characteristic of a broadband network. That means that each connection uses only the bandwidth it requires at every instant of time. Each connection generates a variable bitrate traffic and the network must cope with this kind of traffic. The Asynchronous Transfer Mode (ATM) is defined as a transfer mode where the information flow of a source is organized in fixed blocs, called cells. It is asynchronous in the sense that the interval between successive cells of an individual connection depends on the required or instantaneous bitrate of the information source.

The Asynchronous Time Division (ATD) is a multiplexing technique supporting ATM, wherein a bitstream is structured in time slots carrying cells. A cell consists of an information field and a header. Header values are assigned to each section of a virtual connection at call set-up and released at the end of the call. A specific header value represents a virtual channel.

Switching blocs are composed of switching elements interconnected in some way (multistage structure). The main performance evaluation parameters for a switching bloc are: the mean cell delay, the cell delay jitter and the cell loss ratio. From the designer's point of view, queue dimensioning is a very important aspect and it influences the former three parameters. 
To study the behavior of the switching blocs a set of traffic environments is needed to cover all the possible types of traffic and loads. The main problem, at this time, is that the characterization of the traffic generated by the so called new broadband services is not available yet; there are only some traces for very special services. Furthermore, the cell stream arriving at an input port of the switching bloc is a multiplexed stream of cells corresponding to several connections of different type of traffic sources.

The mean throughput of cells arriving at an input port of the switching bloc is easily obtained for any type of traffic, but it is not enough to characterize the traffic generated by a variable bitrate source which can produce peaks of traffic intensity, let's say, at random. This type of traffic is referred as "bursty" traffic: alternating periods of high activity ("burst") and periods of low activity or silence. High activity periods can produce a mean traffic which is several times the mean traffic of the connection, while low activity periods have a mean traffic lower than that of the connection, or no traffic at all [CHE88] [GEC89] [RID89] [Cos88] .

It is easy to imagine that the behavior of a switching bloc will differ depending on the burstiness of the arriving traffic. One of the most important aspects to evaluate in an ATM network is this behavior of the switching blocs. Several approaches are used to do it but most of them try to construct a "real" traffic for a switching bloc, that is, a multiplexed cell stream traffic corresponding to the traffic of different types of bursty sources, and then to use this mixed traffic.

This method can be summarized as follows: 1) an individual source is modelled accordingly to a type of service and its corresponding burstiness; 2) a given number of these sources is multiplexed to construct the cell stream for a given mean traffic intensity; 3 ) a convenient distribution of each individual 
connection is selected (pairs source - output port are assigned); 4) the simulation is performed using a defined switching bloc and varying the mean traffic intensity at the input ports; 5) the results are studied and confronted with those obtained for other switching blocs (figure 1).

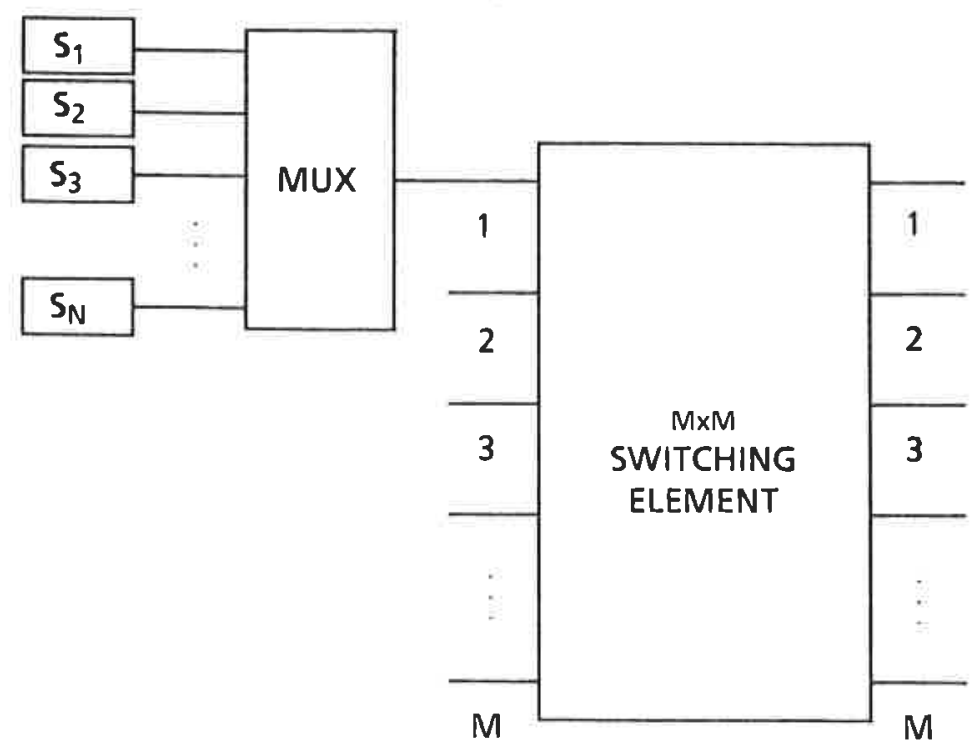

Figure 1. Model for the multiplexation of the cell stream at the input port of the switching bloc

Those approaches require a great number of parameters to define each source and to model their burstiness for a given mean traffic intensity at the input ports of the switching bloc. Such a great number of parameters to fix leads to a great deal of effort performing simulations and requires a lot of cpu time. Furthermore, the results obtained cannot be directly extrapolated to different cases.

The objective of this paper is to present a different approach to evaluate the influence of bursty traffic on the performance of the switching blocs.

At the very beginning we simplify the study using a switching bloc that is composed only of a switching element. In order to focus on this influence of the burstiness we construct a bursty source to model the cell stream arriving at an 
input port of the switching element. This source intends to model the multiplexed cell stream, because what it is really important is to characterize the burstiness of the input cell stream instead of characterizing sources in order to model real traffic as well as possible.

In the next section we present the characterization of the burstiness of the cell stream that is used in this study. The following section explains the traffic source model. After this, the simulation environment defined and the hypotheses considered for this paper is presented. Finally, the results obtained are shown and the discussion of the results concludes this paper.

\section{Burstiness of an ATM cell stream}

There are several definitions for the burstiness in an ATM environment. One of them is the ratio between the peak bitrate and the mean bitrate of a source [KUL84]. Other definitions used are the ratio between the standard deviation of the cell rate and the mean rate or the square of this ratio [COS88]. Another definition states the burstiness as the density of the bursts, that is, the percentage of time the burst is active, and its size, measured as the number of cells of the bursts [FIL89].

We focus our study on the cell stream at the input of the switching bloc where it is the result of the multiplexing of several connections with different types of traffic. So we will not try to model so complex mix but only what would be the join traffic of the connections entering a given input port.

As it has been stated in the previous section the mean traffic intensity is not significant for our purpose because the behavior of the switching bloc for several cell streams with the same mean traffic intensity but different burstiness will be quite different form one another. That's why we need to define more 
accurately the burstiness of a cell stream. We follow the later definition given at the beginning of this section because it is more general and does not restrict to the individual sources.

We define the mean traffic intensity of the cell stream normalized to the cell transmission time, so $0 \leqq \mathrm{~A} \leqq 1$. Parameters like the mean duration of the bursts or high activity periods $(\mathrm{L})$, their mean traffic intensity $\left(\mathrm{A}_{\mathrm{a}}\right)$, the mean interarrival time between activity periods (I), and their mean traffic intensity $\left(A_{S}\right)$ are candidates to model a bursty cell stream (figure 2).

high activity period low activity period

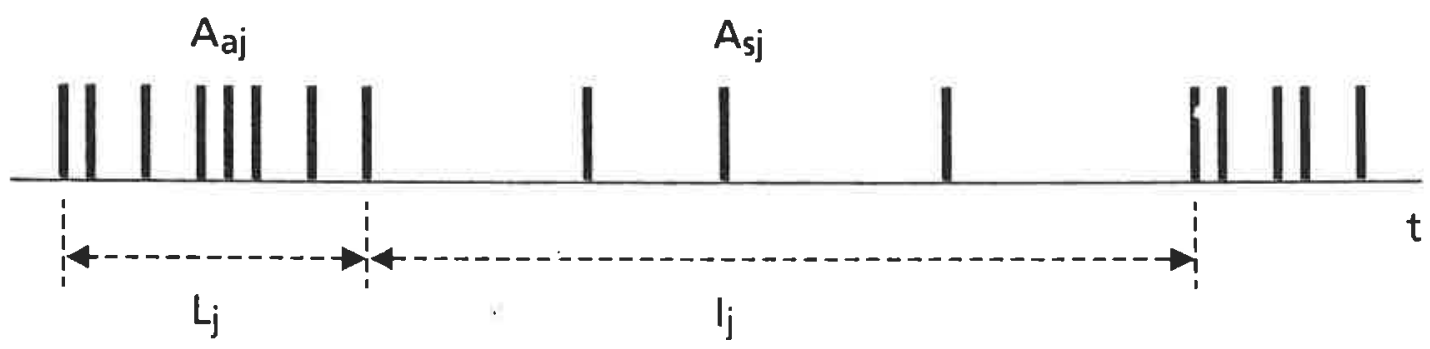

Figure 2. Bursty cell stream characterized by alternating high activity and low activity periods

It has been verified that the relation between these four parameters can determine quite well the burstiness of any cell stream, be it a real trace or be it obtained from models of sources and multiplexing them [SOL89]. The cell stream is analyzed by a program counting the interarrival time between two consecutive cells. This interarrival time is used to identify the high activity periods and the low activity periods (interval of time between two succesive high activity periods). This method is based in that used in [JAI86] to model the "train arrival process". Once these periods are identified the statistical processing is done to get the mean duration and the mean traffic intensity for both of them. The distribution of the cells inside both periods is not very important if the periods are identified correctly. Then a set of values for $L, A_{a}, I$ and $A_{s}$ define a set of cell 
streams with the "same burstiness" from the point of view of the switching bloc behavior.

\section{Traffic Source Model}

The simplest way to model the generation of the cell stream as defined in the previous section is to use a two state model where $\mathrm{L}$ and $\mathrm{I}$ are the state mean sojourn time and $A_{a}$ and $A_{s}$ the probability to generate a cell at each cycle, respectively (figure 3 ). Recall that $A_{a}$ and $A_{s}$ are mean traffic intensities and can

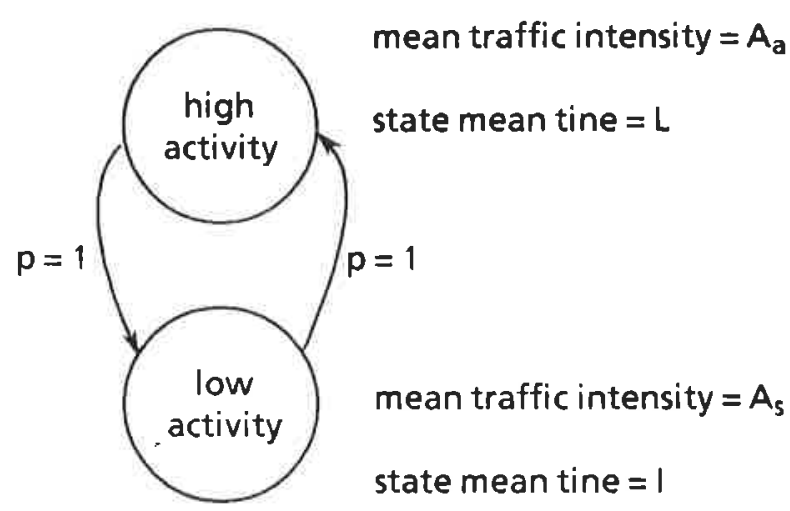

Figure 3. Two state model for generating the bursty cell stream

be taken as probabilities. The cycle is taken as the unit of time and it is equal to the cell transmission time.

The main advantage of using such a simple model is that it is very easy to modify these four parameters to cover a wide range of different bursty cell streams and to fix the mean traffic intensity, A. Besides, it is programmed in an straightforward way and it is not time consuming.

Being $A_{a}$ the mean traffic intensity for the high activity state, the corresponding mean interarrival time of the cells is $1 / \mathrm{A}_{\mathrm{a}}$. For the low activity state, it is $1 / A_{s}$. There are many distribution functions that comply with a defined 
mean. The two simplest approaches are the constant distribution and the geometric distribution. For this first study we have chosen the constant distribution for the interarrival time of the cells in both states.

Respect to the mean sojourn time it is not coherent at all to follow a constant distribution because then the cell stream would be completely deterministic. So, we have selected the geometric distribution.

Focusing on our study of the behavior of the switching bloc with bursty cell streams, it is interesting to fix the mean traffic for an input port $A_{i}$. In order to facilitate the work we needed to reduce the number of parameters to be able to study the behavior of the switching bloc by varying one or two parameters only. As the main interest is to evaluate the influence of the bursts, with their intensity and length, we take $A_{s}=0$, that is, the low activity period is in fact a silence period. Then, it holds true that $A=(L /(L+I)) A_{a}$, and $A_{a} / A=(L+I) / L$.

This expression is similar to the classic definition of burstiness as the peak traffic intensity devided by the mean traffic intensity, but we take the definition of burstiness the other way round, $\mathrm{B}=\mathrm{E}[\mathrm{L} /(\mathrm{L}+\mathrm{I})]$ as like that one used in [FIL89]. Then, B could be seen as the percentage or probability of a burst.

With the two state model, once fixed $\mathrm{A}$ and $\mathrm{A}_{\mathrm{S}}=0$, it holds that $A / A_{a}=L /(L+I)$ fixes the $I / L$ ratio, tha! is fixes $B$, because with the statistical characterization that we have adopted $B$ is a function only of this ratio

$$
B=\frac{L n(I / L)+L / I-1}{I / L+L / I-2}
$$

Varying the mean traffic intensity of the burst $A_{a}$ and its mean length $L$ the value of $I$ is determined. For a value of $A_{a}$ several values of $L$ may lead to the same burstiness B. 


\section{Simulation environment}

For this study we take a switching bloc of size $16 \times 16$, which is a crossbar with queues at each crosspoint (matrix of slotted buses) (figure 4) [COS88]. The

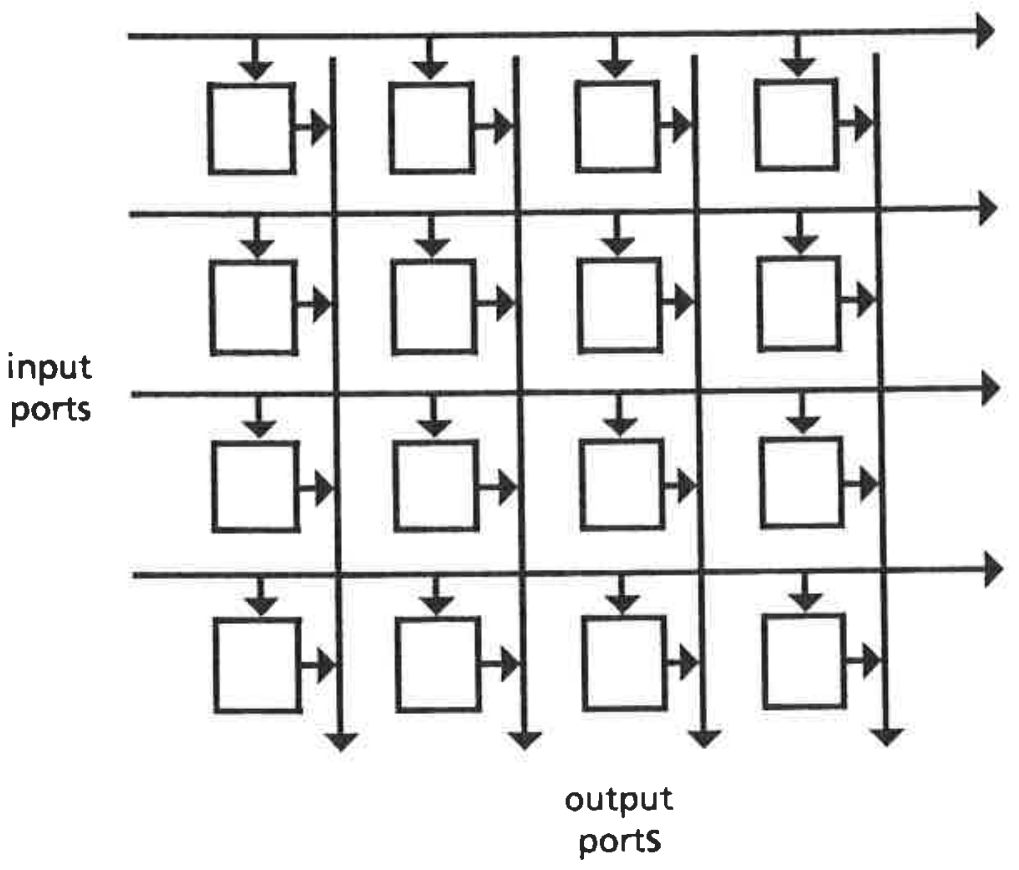

Figure 4. Crossbar switching element with queues at the crosspoints (Size $4 \times 4$ )

management of the queues corresponding to one output port (queue of the same column) is done as a global FIFO policy. That means that in case of more than one queue having a cell to output the oldest one is taken; in case of conflict, random selection is done. In this way the behavior of one of the queues may be generalized to the other ones.

Other parameters of the system are: the bitrate of the channel is $600 \mathrm{Mbps}$; the cell length is 48 information bytes plus 5 bytes for the header, that is $0.7 \mu \mathrm{sec}$ per cell, as proposed recently in the last CCITT meeting; the mean traffic intensity of each channel is fixed to be 0.8 (channel load). The unit of time is the cycle taken as the cell transmission time. 
As it has been told above, we model the cell stream arriving at an input port of the switching bloc with the two state model presented in the previous section. This cell stream is formed by the multiplexation of many individual traffic sources, but we are not interested in the burstiness of the sources but only in the burstiness of the cell stream entering the switching bloc.

An additional aspect to be taken into account is that we try to consider the worst case situation. This multiplexed cell stream contains cells from different connections (virtual circuits). From the point of view of the switching bloc we are modeling the burst than can fill a queue at the crosspoints which is formed by cells going to the same output port, $i$. All the other cells going to output $j$, being $j \neq$ $i$, will not cause any trouble in the switching bloc. So, if $A$ is the trafic intensity of one channel, assuming that all virtual circuits are distributed uniformly among the 16 output ports, the traffic intensity of the bursty cell stream we are interested in is $A_{i}=A / 16=0.05$. Then, using the parameters of the two state model, $A_{i} / A_{a}=L /(L+I), A_{a}=(L+I / L) A_{i}$.

The assumption that is behind this model is that cells going to the other output ports do not interfere with the burstiness of thę cell stream going towards output i. In fact, these cells can be considered to be located in the cycles within the bursts where there is no cell, or, simply, to be located in the silent periods. In that sense, the bursty cell stream generated could be considered as a worst case situation. Moreover, it is sufficient to analyze the results for one output port only.

The values of the burstiness (B) taken vary form 0.25 to $0.61 . \mathrm{B}=0.25$ is obtained for $\mathrm{A}_{\mathrm{a}}=6 \mathrm{~A}_{\mathrm{i}}=0.3$, which corresponds to a burst bitrate of $180 \mathrm{Mbps}$. For $\mathrm{A}_{\mathrm{a}}=1.5 \mathrm{~A}_{\mathrm{i}}=0.075, \mathrm{~B}=0.61$ and the bitrate in the burst is $45 \mathrm{Mbps}$. Recall that the mean bitrate of the cell stream considered is $A_{i} 600=30$ Mbps. 
The values of the mean length of the burst, $\mathrm{L}$, vary form 200 cycles to 20000 cycles, that is, from $140 \mu \mathrm{sec}$. to $14 \mathrm{msec}$., in order to cover a wide rage of situations that can be produced when multiplexing diferent types of bursty sources.

The simulator is a special purpose program, in order to optimize CPU time, for this is the major constraint. The program is written in VMS PASCAL, and it has been ran on a Vax Sation 3200. In order to obtain a good confidence interval for the measurements, a replication technique is used. The simulation run is divided into several batches that obtain the mean values of the most significant parameters. At the end, all these means are averaged to obtain the final value and the confidence interval (95\%).

In this case, 5 repetitions of 10 million cycles are done, which corresponds approximately to $3.5 \mathrm{sec}$. of real time, and a transient period of 1 million cycles is done at the beginning. The cpu time required for each simulation is about 6 hours.

All buffers are assumed to be infinite, and the buffer occupancy distribution function is measured for each queue. From this result, the needed buffer size can be estimated. The buffer occupancy is sampled at each cell arrival time instant, that is, when a cell has just entered the buffer.

The queue length distribution is computed for all 16 queues of the column. The average and standard deviation of this distribution and the maximum queue length for each queue are also computed. At the end, the 16 distributions are averaged and a total queue length distribution, its mean, standard deviation and maximum value, are obtained.

The delay distribution is computed along the whole simulation run. Its mean, standard deviation and maximum value are computed at the end of the simulation. 


\section{Results}

In order to compare the results obtained we have done the simulation for a cell stream without bursts ( $I=0$ and $A_{s}=0$, then $A_{a}=A$ ) and we take its results as a reference.The mean occupancy of the queues is 0.12 and its maximum is 8 . The mean delay is 3 cycles approximately, that is, about $2.12 \mu \mathrm{sec}$. The standard deviation for the cell delay (delay jitter) is about 2.4 cycles and its maximum is 33 cycles.

The curves of the mean occupancy of the queues respect to the mean length of the burst (L) for the different degrees of burstines (B) show that the occupancy grows almost linearly with the burst length (Figure 5).

The mean occupation of the queues is larger than 1 cell in the following cases: 1 ) for $B=0.61$, which implies $A_{a}=1.5 A_{i}, L=5000$ cells and $I=2500 ; 2$ ) for $A_{a}=2 A_{i}(B=0.5)$, then $L=1000$ and $I=1000$; and 3) for $A_{a}=3 A_{i}(B=$ $0.38), \mathrm{L}=200$ and $\mathrm{I}=400$. As the burstiness is higher (B lower) shorter bursts prevent the queues to have a mean occupation less than one cell. It can be observed also in the curves that for $\mathrm{L}=2000$ the mean occupancy is 7.3 cells for $\mathrm{B}$ $=0.38$. That means that 300 cells spread within 2000 cell time and followed by a silent period of 4000 cell times (all these are mean values) cause a mean occupancy of 7.3 cells.

The curves of the mean delay versus the length of the burst for different values of the burstiness show a linear behavior with a greater slope as the burstiness is higher. For $\mathrm{B}=0.38$ and $\mathrm{L}=2000$ the mean delay is 134 cells, taht is about $0.1 \mathrm{msec}$. Recall that for a non bursty cell stream this value is $2.12 \mu \mathrm{sec}$. 


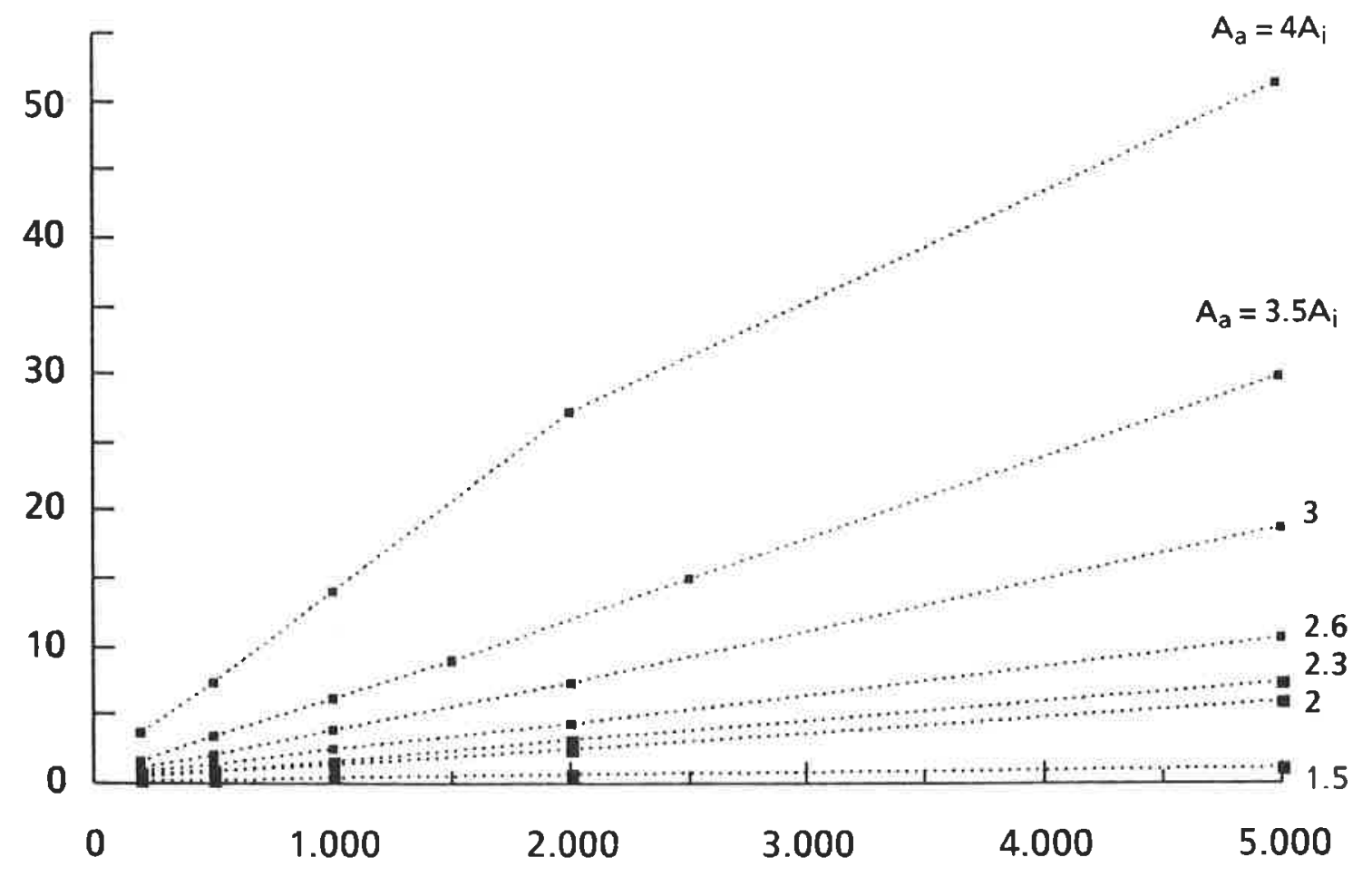

Figure 5. Mean queue occupancy versus mean burst length

Interesting conclusions can be derived from figure 6 which represent the queue size needed to have cells lost with a probability less than 10E-10. In case of non bursty cell stream this queue size is 10 cells. For $B=0.5$ and $\mathrm{L}=200$, which is a short burst, the buffer size needed is 20 , that is about $8 \mathrm{Kbytes}$ per queue. We can say that "weak" burstiness lead to such a behavior that the size of the queues required to have the cell loss ratio stated before is too much exaggerated.

Finally, figure 7 shows the values of the probability that the mean delay is greater than $0.1 \mathrm{msec}$. respect the mean burst length. We can observe that even for relatively short bursts, $\mathrm{L}=500$, the probability that the delay is greater than $0.1 \mathrm{msec}$. is greater than 0.01 . 


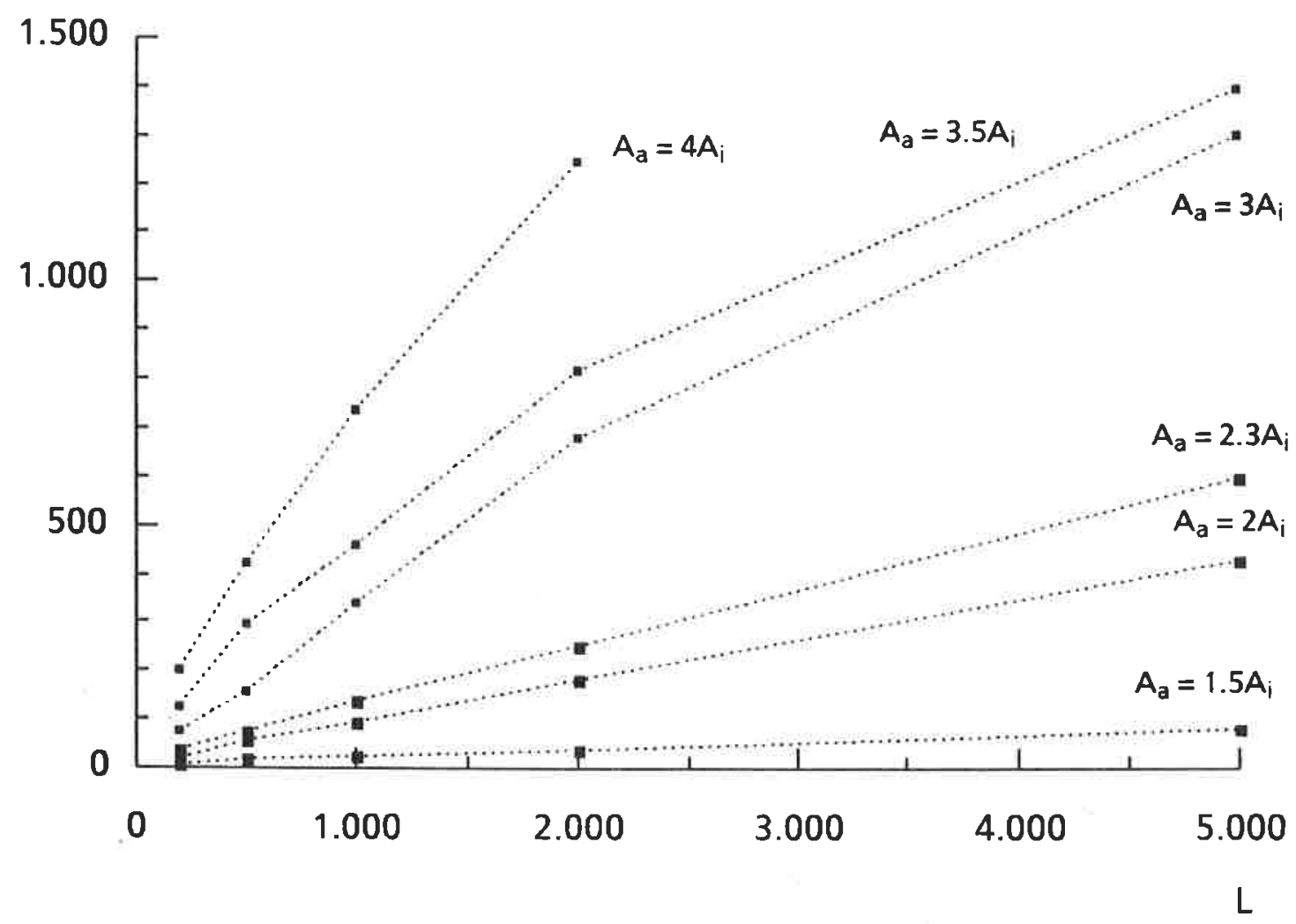

Figure 6. Buffer size for a cell loss probability $<10^{-10}$ versus mean burst length

Intuitively, summarizing the results obtained in this study, it seems that there should be a value for the mean burst length (L), different for each mean burst traffic intensity $\left(A_{a}\right)$, that is critical in the sense that for larger values than this, the performace of the switching bloc is degradated below acceptable working conditions.

\section{Conclusions}

In this paper, a characterization of a bursty cell stream has been developed focusing on the length and the mean traffic intensity of the haigh activity periods. A definition of burstiness of a cell stream is given according to these parameters. 


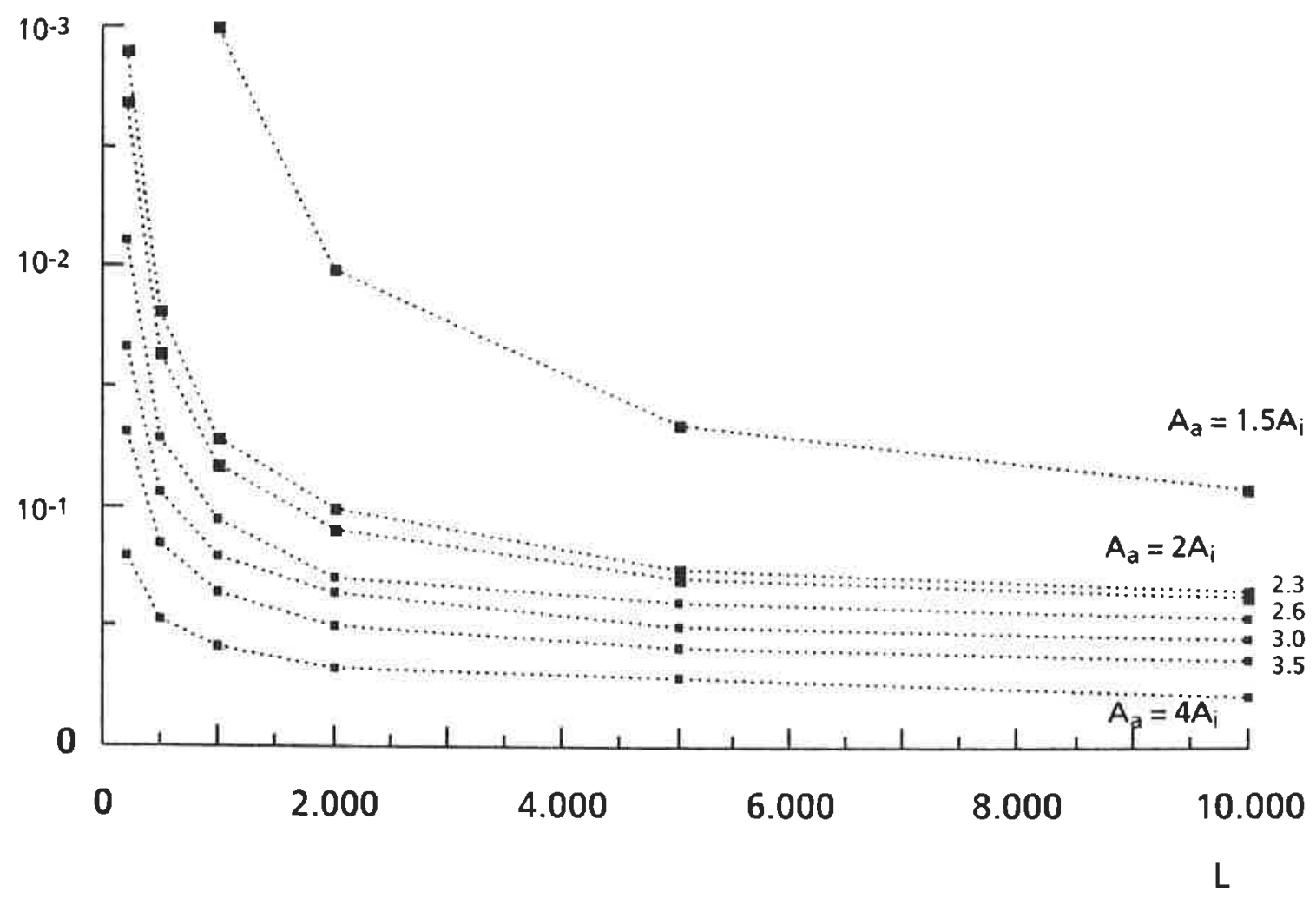

Figure 7. Probability that mean delay $>0.1 \mathrm{~ms}$. versus mean burst length

A two state model to generate bursty cell streams has been presented and used in the simulations for studying the behavior of a switching bloc. The simulations cover a wide range of possible situations that correspond to the burstiness of a multiplexed cell stream at the input of a switching bloc.

Results show that a "weak" burstiness of the cell stream, as defined in the paper, can cause drastic reduction of the switching bloc performance, producing large delays and high cell loss ratios. In order to prevent cell loss, very long queues are needed to cope with little degree of burstiness.

The next step to continue this work is to release the condition of using a silent state in the cell stream model $\left(\mathrm{A}_{\mathrm{S}} \neq 0\right)$, and to model the interarrival time between cells as a geometric distribution. In this way the cell stream generated 
should be more similar to a real multiplexed cell stream. That's to say, now we try to reproduce the burstiness characteristics of real cell streams with the two state model.

With a representative sample of cell streams a "test bench" can be developed to analyze and evaluate multistage switching blocs and different switching architectures also.

\section{References}

[KUL84] J. J. Kultzer, W. A. Montgomery, "STATISTICAL SWITCHING ARCHITECTURES FOR FUTURE SERVICES". ISS 1984, 43.A1.

[JAI 86] R. Jain, S. A. Routhier, "PACKET TRAINS -MEASUREMENTS AND A NEW MODEL FOR COMPUTER NETWORK TRAFFIC". IEEE Journal on Selected Areas on Communications, Vol. SAC-4, no. 6 (September, 1986) pp. 986-995.

[COS 88] Expert Group on ATM Switch Structures. "FINAL REPORT OF COST 202bis". December, 1988.

[CHE 88] T. M. Chen, D. G. Messerschmitt, "INTEGRATED VoICE/DATA SWITCHING". IEEE Communication Magazine, vol. 26, no. 6 (June, 1988), pp. 16-26.

[FIL 89] J. Filipiak, "M-ARCHITECTURE: A STRUCTURAL MODEL OF TRAFFIC MANAGEMENT AND CONTROL IN BROADBAND ISDN". IEEE Communication Magazine, vol. 27, no. 5 (May, 1989) pp. 25-31.

[GEC 89] J.Gechter, P. O'Reilly, "CONCEPTUAL ISSUES FOR ATM". IEEE Network (January, 1989) pp. 14-16.

[RID 89] M. J. Rider, "PROTOCOLS FOR ATM ACCESS NETWORKS". IEEE Network (January, 1989) pp. 17-22.

[SOL89] J. Solé, J. García, J. Domingo, "BURSTY CELĹ STREAM CHARACTERIZATION". Internal Report. Facultat d'Informàtica de Barcelona, FIB 1989. 